\title{
Juridical Analysis of Criminal Act Against Nation Ideology in Indonesian Criminal Law
}

\author{
$1^{\text {st }}$ Reynold Simandjuntak \\ Law Study Program \\ Universitas Negeri Manado \\ Manado, Indonesia \\ reynoldssimandjuntak@unima.ac.id
}

\author{
$2^{\text {nd }}$ Wenly R.J. Lolong \\ Law Study Program \\ Universitas Negeri Manado \\ Manado, Indonesia \\ wenly.lolong@unima.ac.id
}

\author{
$3^{\text {rd }}$ Gelar Ali \\ Law Departement \\ Faculty of Sosial Sciences and Law \\ Universitas Negeri Surabaya \\ Surabaya, Indonesia \\ gelarahmad@unesa.ac.id
}

\begin{abstract}
A nation that want to lived firmly, the way of life is really important to not be tossed around in facing issues in the society. Then with clear way of life then a nation would have something hold and guidelines in solving the political, economy, social, and cultural problem. The issues that being discussed were first, whether that became the thinking fundamental about the criminal act towards national ideology regulation? Second, whether the formulation of criminal act toward national ideology already reflected the legal protection for the society? From philosophy, sociological and juridical point of view the regulation about criminal act toward the ideology were really needed to provide the protection for national laws interest. Because the ideology existence in a nation as guidelines to held a nation that unite the nation, providing the formulation about past situation, now and regulate strategical move to reach the nations dream, also providing the game rule in political and social life in effort to achieve prosperity.
\end{abstract}

Keywords - Criminal Act, Nation Ideology.

\section{INTRODUCTION}

Historically, this crime regulation related with the emergence of Temporary People Consultative Assembly Indonesian Republic (In Bahasa: MPRS) Number XXV/MPRS/1966 about the dismissal of Indonesian Communist Party and declaring as restricted organization in Indonesian Republic nation territory for the Indonesian Communist Party and restriction to every activity spread or developing Communism/Marxism-Leninism ideology or teaching.

After an event in 1965 the usually known as $30^{\text {th }}$ September Movement (G 30 S PKI), ICP considered intended to replace the Pancasila ideology with Communism, Marxism, Leninism or so forth ideology. In its journey in the new order era, the MPRS policies are adequately effective to reject or even eradicate all organization that considered as communist or marked as communist "Leftist".

Just then in Habibie governance (the beginning of reformation) emerge Laws Number 27 Year 1999 about the revision of Criminal Laws Book (KUHP) that related with crime towards the national security. The Laws Number $27 / 1999$ explicitly regulate about the restriction of spreading the leftist ideology and insert 6 article in I chapter- about crimes toward national security - KUHP, that is between the Verse 107 and 108, that became Verse 107 a, Verse 107 b, Verse 107 c, Verse 107 d, Verse 107 e, Verse 107 f .

In the Laws Number 27 Year 1999 basically regulating two kind of crimes, that is: crimes that related with the Pancasila as nation ideology replacement and sabotage crime, especially sabotage to military facilities and infrastructure and sabotage to the distribution or staple procurement.

MPRS provision XXV/1966 and Laws Number 27 Year 1999, till now still prevail. Can be said that the existence of both laws that became the origin of the emergence of ideological criminal act in KUHP revision (R KUHP) and since the emergence of Laws Number 27 Year 1999 that the be known as the new terminology in Indonesian criminal law, that crimes toward the nation ideology. That terminology then be concreted in R KUHP in chapter I about National Security Criminal Act, the first part about Criminal Act with Nation Ideology.

The maintained of criminal act criminalization that related with this ideology are the consequences of prevailed MPRS Provision Number XXV/1996 and the birth of MPR Provision Number XVIII/1998 about the averment of Pancasila as nation foundation. Moreover, because of the law emptiness because the revocation of Laws Number 11 PNPS Year 1993 about the Subversion through Laws Number 27 Year 1999 and the birth of Laws Number 27 Year 1999 about the changes of KUHP that related with national security crime.

Generally, the verses formulation of the crime toward ideology still covered with some issue that need to be revised. Among them, that related with verses formulation itself, the bad effect for human rights, also the understandings that need further examination, whether the understanding about Pancasila as ideology or nation foundation. Will be explained some essential matter about the existence of the crime in R KUHP [1].

In facing live troubles every human being has to had grips or principal as a foundation to solving the problem. If doesn't have one, the human kind would be tossed around by 
the trouble that they faced, especially the fundamental matter, for example what and for what this life is.

If humankind cannot answer the fundamental circumstances about life, like what and what life for, then can be confirm that they have difficulties to answer another easier circumstance correctly. This would impact the uncertainly of life direction. That is why the grip or principal are really vital and a fundamental human need. Principal or foundation that based the answer on the fundamental cicumstances about life usually called as way of life. Way of life also be called pandangan hidup, weltanshauung, wereldbeshouwing, wereld en levensbeschouwing, way of life, life guideline and life instruction [2]. With way of life human kind will be lead to essential ideal life.

Someone way of life can be different with another person. That seem reasonable because the way to think, feel experience of a person were different than the other. A nation that expecting to have affirm life, way of life was really important so that not be tossed around in facing the problem in its own people or the bigger problem of humankind in socializing with another nations in the world. Then with clear way of life will have something to hold on and guideline for solving political, social, and cultural problem people life movement that improving and also for self-development. In another words, it is a must for a nation to have ideology.

In social community and nation life ideology function, among others:[3]

1. In the society that experiences ideology stagnancy often can stimulate the relief of community or society and welcome the new situation that promoted.

2. Ideology as way of life in nation activity society can unite the nation, providing the national situation formulation in the past, present and to preparing the strategic move in reaching to the situation that be wanted.

3. Ideology provides the rule of game in the society and nation life in order to achieve communal prosperity.

With consideration in Pancasila position as the ideology of Indonesia nation, then the government assumed to perform the protection to the ideology existence, through criminal laws policies, the protection of Pancasila as ideology is an implementation of protection on national jurisdiction interest.

According to the background above that became the main question from this writing are, Firstly; whether the fundamental thought about the existence of criminal act toward nation ideology regulation? Second, whether the formulation of criminal act to nation ideology reflects the jurisdiction protection to the people.

\section{RESEARCH METHODS}

This research was normative jurisdiction research that a research that obtain legal materials in the way of collecting and analyze the legal material that related with the problem that would be discuss. While the research tends to be descriptive, that describe the answer of the problem through the writer research findings. As for the legal material sources including the Primary legal material in form of, law regulation, Secondary legal material in form of books/literature, article, magazines, lawyer writings, lawyer opinion, also scientific works that related with this research.

\section{RESULTS AND DISCUSSION}

\section{A. The rationale of the needs of criminal act to the nation ideology}

The term of ideology came from the word idea that means thought, concept, basic understanding, dreams; and logos that mean science. Etymologically ideology, means the science of ideas, or doctrine about basic understanding [4]. In Indonesian language great dictionary ideology define as collection of systematic concepts that made from opinions that provides direction, and purpose to living the life. Ideology also be interpreted as the way of thinking of a person or a group. Ideology can be interpreted as the concept, theory, and purpose that became one of the socio politic program [5]. In that understanding, we obtain some important components in ideology that is system, direction, program, social and politic.

The historical concept of ideology can be traced further before the term was used by Destutt de Tracy in the end of eighteenth century, Tracy said that ideology as the science of ideas, that is a program that expected can brought institutional changes for the French people. However, Napoleon criticize the ideology term that he assumed just an imagination, and does not have practical significance. That kind of thing will not be found in reality [6].

The open ideology special features are that the values and purposes not be force from outside, but it be excavated and be taken from spiritual, morality, and people culture resources itself. Basically, people consensus could not be created by the nation, but found in society itself. That is why open ideology are belong to all people and community that found themselves in it. Open ideology not only correct but were needed. The fundamental values based from modern country perception that the modern country exist because the fundamental values and attitudes.

Open ideology is an ideology that could interact with current development and the internal dynamically. The source of open ideology spirit was actually could be found in General Explanation of Fundamental Laws 1945 (UUD 1945), that stated, "especially for the new nation and young nation, its better if the fundamental laws that be writes only contain the main laws, while for the regulation that execute those fundamental laws be submitted to the easier laws from the way it created, changed and revoke". Then it stated, "the really important thing on governance and nation life it's the spirit, the organizer spirit, the spirit from the government leaders". So that Hatta suggested that the elite can be crueler than the invader if not be controlled with democracy.

The essence that influence the challenges to Pancasila as nation ideology including internal and external factor. There is external factor include in the following matter:

1. The ideology battle between superpower countries like United States of America and Soviet in 1945 to 1990 and ends with the dismissal of Soviet country and makes America the only superpower country. 
2. The global culture issue that getting stronger and marked by the penetration of various foreign ideology in nation society and community because the information transparency.

3. The world needs that increasing as the impact of increasing population and the development of ideology, and cause massive exploitation to the natural resources. The concrete impact is natural damage for example, flood, burned forest.

And internal factor that include following matter:

1. Regime alteration that in charge to create public policies that oriented by certain group or party interest so that the Pancasila ideology often be ignored.

2. The misused of authority (corruption) caused the poor people credibility to the authorize regime so that the credibility for ideology were drastically decreased.

Nation ideology role were not only from legal formal aspect, but also has to be present in the concrete life of the people itself. Some concrete role for Pancasila as ideology can be include as follows:

1. Nation ideology as citizen guidelines, means that every citizen attitude has to be based with moral prescription. For example, narcotic case that spread to the young generation shows that the moral ideology prescription does not be realized its presence. That is why, clearer guidelines norms were needed, whether in more appeal persuasive form, or Pancasila values explanation in the form of law product that provide clearer signs and fair punishment for the violator.

2. Nation ideology as rejection for the values that inappropriate with the essence of Pancasila. For example, terrorism case that happen in form of enforcement of will through violation. This matter are contradict with toleration values, that belief in human rights and the spirit of unity.

Pancasila rooted to the way of life of nation and nation ideology, so that fulfilled the requirements to be an open ideology, even if the ideology that tend to be open, does not mean that the openness in some kind of way could eradicate or demolish its own ideology that an illogical thing. An ideology as the summarization of the whole and integrated fundamental ideas without contradict or contradicting in its aspects. Essentially like a organize value, where the value that we could formulate as essentially good or bad the matter.

Pancasila as an ideology were not stiff and enclosed, but reformative, dynamic, anticipative, and capable to adapt with the current development, science and technology also the dynamic people aspiration development, Pancasila ideology transparency does not mean to change the fundamental values that be contained in it, but explicit the knowledge in more concrete way, so that obtain the more reformative abilities to solve the actual problems and constantly develop in line with citizen aspiration..
Kaelan propose that open ideology including the contained values in Pancasila ideology as open ideology as follows:[4]

The fundamental values that the essence of all five verses are divinity, humanity, unity, democracy, and justice. Those fundamental value are the essence from the verses of Pancasila that universal, so that in those fundamental values contains the dreams, purposes that good and correct. Ideology fundamental values contained in Fundamental Laws Introduction 1945 (Pembukaan UUD 1945) because of the Law Introduction contained fundamental values of Pancasila ideology then the UUD 1945 booking were the fundamental norm that the highest law order, as a positive law sources in the country stood as "Staatsfundamentalnorm" or the main principle that fundamental and related with the nation living life. As open ideology the fundamental values that being permanent and because of UUD 1945 also contained the fundamental values then the UUD 1945 also have permanent tendencies and related directly with the nation living life, so that changing the UUD 1945 that contained the fundamental values as same as to dismiss the nation then. And the fundamental values then be explained in UUD 1945 articles that in it contained the national institutions, relation between institution and with nation administrator tasks and authority.

Instrumental values, that a direction, policies, strategy, target also the institutional operator, this instrumental value were the explication, further explanation from the fundamental values in order to adapt in Pancasila ideology fundamental values implementation. For example, the National Course Outlines (GBHN) that every five year always be adapted with the current development also people aspiration, laws, departments as the executional institution and other. With this aspect the reformative could be done constantly.

Practical value is the realization of the instrumental values in a realization experience that real, in the daily life in civilization of the nation (see BP-7 Main, 1994:8). In his practical realization then Pancasila values be describes constantly develop and always available for changes and improvement (reformation) suitable with current development of science and technology also people aspiration.

The factors that encourage the idea about ideology transparency are as follow:

1. The reality that in national development process and the society dynamics rapidly develop.

2. The reality shows the bankrupts of closed and frozen ideology caused by tendency to dim their development.

3. Our political history experience in the past.

4. The will to strengthen the awareness of the Pancasila fundamental values that immortal and desire to be improve creatively and dynamic in order to reach the national purpose.

The transparency of Pancasila ideology especially aimed the implementation with form of shapes the thinking pattern that dynamics and conceptual in modern world. We knew 
that there are three values level that is permanent fundamental values that could not be changed, instrumental values as devices to implicate the fundamental valued that can be changed based on the condition and practical value that form as the realization or implementation. Pancasila values described in the fundamental norms of Pancasila that contain and reflected in UUD 1945. Fundamental values or norms that contained in UUD 1945 could not be changed or change. That is why there are option and nation consensus result that known as the nation main principle that fundamental (Staatsfundamentalnorm). The forming or implementation of instrumental values and practical values have to embody the same soul and spirit fundamental values. The truth of thinking pattern just like described above were suitable with ideology, that possessed three important dimension that is, Reality Dimension, Idealism Dimension, and Flexibility Dimension [7].

In UUD 1945 in fourth paragraph stated that:

"......then the freedom of Indonesian nation formed in an Fundamental Laws of Indonesian nation, that shaped in an arrangement of Indonesia Republic Nation that democratic that based to: belief in one supreme god, civilize and justice humanity, the unity of indonesia and democracy that led by the wisdom mind and wisdom in deliberating representatives also creats social justice for all the people of Indonesia" [8].

All five of nation foundation known as Pancasila. Therefore, the Indonesia countries foundation are Pancasila. The nation foundation also called as nation principal foundation, philosophische grounslag and often be called as nation ideology [9]. Between nation and nation foundation had to compatible. In this matter the nation have to adapt with the foundation, that is Pancasila. National foundation had to be steady and firm. If does not firm or if the nation foundation be changed, then the nation will fundamentally change. The fundamental nation changes can be articulate as forming a new nation.

From Indonesia state administration laws, Pancasila as the nation foundation that essentially the origin of all laws sources like stated in MPRS provision Nu. XX/MPRS/1966 juncto MPR-RI provision $\mathrm{Nu}$. V/MPR/1973 and provision $\mathrm{Nu}$. IV/MPR/1979. The origins of all sources means way of life, awareness and juridical purpose also moral purpose that covers the mental condition also Indonesia nation face [2]. Whale in provision MPR Nu III/MPR/2000 Pancasila be called as National Fundamental Legal Source.

As the origins of all legal sources, Pancasila position really fundament for nation organizer. That matter considering nation is form of human cooperation to fulfil their needs as Plato said that [10]. As an organization, nation no necessarily run without its rule.

In its journey a nation has to be ruled, so that can reach the destination that already be determined. The rule generally be said as principal. In society there a lot of kind of principal. Belief or spiritual principal, decency principal, attitude principal and law principal [11].

In organizing a nation life, the most dominant thing is law principal. Since its inception, the Founding Fathers already declared that Indonesia as juridical nation. The matter occurs in UUD 1945 description about the state government system that stated "Indonesian as Law based country (rechstaat), not only based on the authority (machtstaat)".

From the explanation above describes the remarkable position and the ranks of Pancasila in a country, Pancasila as ideology and became the guidelines of the policies in organizing the nation, in explanation part of Laws Nu. 27 Year 1999 about the reformation of Criminal Laws Book that related with the National Security Crimes then main consideration that this law presented are an effort to defend Pancasila as nation foundation from thread and danger of Communism/Marxism-Leninism doctrine that proven to be contradict with religion, principle and Indonesian living life that belief in God and from another criminal act that endangered national security, In order to this reason then the importance to reform the Criminal Laws Book to added verses that related with crimes towards nation security.

In this context when the intended laws, be presented in effort to defend Pancasila as nation foundation then it important to creates criminal verse for threats and punish the activity or doing that considered to endanger the Pancasila position as nation ideology.

\section{B. Criminal act toward nation ideology regulation}

The birth of Laws Nu. 27 Year 1999 about the reformation of Criminal Laws Book that related with Nation Security to fill the law void in ideology crimes sector the consequence from the revoke of Laws $\mathrm{Nu} 11$ PNPS Year 1999 about the Subversion Activity Eradication. While another fundamental thought in the birth of Laws Number 27 Year 1999 were the first, that the Criminal Laws especially that related with the regulation about crimes toward nation security does not give significance contribution in law foundation in effort to defend the unity of Indonesia United Republic that be based with Pancasila as nation foundation. Second, the doctrine and teaching of Communism/Marxism/Leninism in politic life practice and statehood transform themselves in activity that contradict with principle and life of Indonesia nation that belief in God and have religion also proven to endanger the living life of Indonesia nation.

In Laws Number 27 Year 1999, crimes toward nation ideology formulated as follows:[12]

1. Verse 107a: anybody that publicly oppose the laws whether in verbal, writings, and or through any media spreading or developing Communism/Marxism-Leninism doctrine in any form will be punish with cell Punishment with longest time are 12 (twelve) years.

2. Verse 107b: anybody that publicly oppose the laws whether in verbal, writings or through any media then declare the desire to eradicate or replace th Pancasila as nation foundation that resulted the emersion of riot in society or causing fatality or loss of wealth, punish with cell punishment with the longest time are 20 (twenty) years. 
3. Verse 107c: anybody that publicly oppose the laws whether in verbal, writings, and or through any media spreading or developing Communism/Marxism-Leninism doctrine and resulted the emergence of riot in society, or creates fatalities or wealth loss, punish with cell punishment the longest time are 15 (fifteen) years.

\section{CONCLUSION}

From philosophical, juridical and sociological point of view point the regulation about criminal act toward ideology were really important in providing protection to nation juridical interest. howsoever, the existence of ideology in a nation were as guidelines in nation living-hood that can unite the nation, providing formulation from nation situation in the past, present and organize strategical move in order to reach nation purposes, also providing the rule of game in political life and socialized in effort to achieve the communal prosperity.

The formulation of criminal act to ideology that stated in Laws Nu. 27 Year 1999 about reformation of Criminal Laws Book that related with crimes toward national security, contained a lot of weakness especially in formulating an act that be categorized as criminal act toward ideology, the formulation that presuppose with multi-interpretation that in the end will resulted with uncertainly of law and human rights violation.

\section{REFERENCES}

[1] S. W. Eddyono, "Problem Kejahatan Terhadap Ideologi Negara Dalam R KUHP _." [Online]. Available: http://reformasikuhp.org/problem-kejahatan-terhadap-ideologinegara-dalam-r-kuhp/. [Accessed: 31-Jul-2018].

[2] S. Al Marsudi, Pancasila Dan UUD 1945 Dalam Paradigma Reformasi. Jakarta: Raja Grafindo Persada, 2001.

[3] P. Wahana, Filsafat Pancasila. Yogyakarta: Kanisius, 1983.

[4] M. S. Kaelan, Negara Kebangsaan Pancasila: Kultural, Historis, Filosofis, Yuridis dan Aktualisasinya. Yogyakarta: Paradigma, 2013.

[5] Departemen Pendidikan Nasional, Kamus Besar Bahasa Indonesia. Jakarta: Gramedia Pustaka Utama, 2008.

[6] M. S. Kaelan, Pendidikan Pancasila. Yogyakarta: Paradigma, 2003.

[7] A. A. Agus, "RELEVANSI PANCASILA SEBAGAI IDEOLOGI TERBUKA DI ERA REFORMASI A. Aco Agus Fakultas Ilmu Sosial, Universitas Negeri Makassar," J. Off., vol. 2, no. 2, pp. 229-238, 2016.

[8] Republik Indonesia, Undang-Undang Dasar Negara Republik Indonesia Tahun 1945. .

[9] H. A. M. Effendy, Falsafah Negara Pancasila. Semarang: Duta Grafika, 1989.

[10] P. Busroh, Ilmu Negara. Jakarta: Bumi Aksara, 2001.

[11] S. Mertokusumo, Mengenal Kaidah Hukum. Yogyakarta: Liberty, 1996.

[12] Republik Indonesia, Undang-Undang Nomor 27 Tahun 1999 tentang Perubahan Kitab Undang-Undang Hukum Pidana yang Berkaitan dengan Kejahatan Keamanan Negara. . 